Thorax (1976), 31, 278.

\title{
Oesophageal motor changes in diabetes mellitus
}

\author{
I. M. STEW ART, D.J. HOSKING, B. J. PR ESTON, \\ a nd M. A T K I NSON
}

General Hospital, Nottingham

\begin{abstract}
Stewart, I. M., Hosking, D. J., Preston, B. J., and Atkinson, M. (1976). Thorax, 31, 278-283. Oesophageal motor changes in diabetes mellitus. Radiography and manometry have been used to study oesophageal motor function in a group of 31 diabetics, 23 of whom had alimentary or genitourinary symptoms attributed to autonomic neuropathy. Peristalsis was of diminished amplitude and oesophageal emptying in the $15^{\circ}$ Trendelenburg position was delayed. The lower oesophageal sphincter pressure was reduced. The changes seldom caused symptoms and they were not confined to those diabetics with alimentary or genitourinary symptoms attributable to autonomic neuropathy. They suggest that autonomic neuropathy in diabetes is widespread and of ten subclinical.

Degeneration of the ganglion cells of the oesophageal myenteric plexus is associated with hypersensitivity of the oesophageal smooth muscle to cholinergic agents. Bethanecol, a cholinergic drug with muscarinic actions, accelerated oesophageal emptying and increased the lower oesophageal sphincter pressure to normal levels in our diabetics but the hypersensitivity to this drug found in the presence of ganglion cell degeneration was not seen. This implies that in diabetic autonomic neuropathy the predominant lesion is in the preganglionic fibres of the vagus rather than in the myenteric plexus of the oesophageal wall.
\end{abstract}

Disturbance of gastrointestinal motility in diabetes is well recognized and may cause nausea, vomiting (Kassander 1958; Dotevall, 1961), constipation, and diarrhoea (Rundles, 1945; Malins and Mayne, 1969; Whalen, Soergel, and Geenen, 1969). Oesophageal symptoms are much rarer but oesophageal manometric abnormalities in diabetes have been reported by Mandelstam et al. (1969) who found diminution in the amplitude of peristalsis and reduction in the lower oesophageal sphincteric pressure. Tertiary contractions were common, but, when present, peristalsis was properly coordinated. In contrast, Silber (1969) found incoordination of oesophageal peristalsis in diabetic patients which did not correlate with the presence of peripheral neuropathy, and indeed similar changes were noted in non-diabetics with no oesophageal symp.oms.

The present study was undertaken to determine whether specific oesophageal motor changes occur in diabetes and, if so, to clarify their nature and to determine whether they are associated with impairment of vagal function.

\section{PATIENTS}

Thirty-one diabetic patients were studied (Table I).
Of these 13 had alimentary symptoms thought to be due to autonomic neuropathy, 10 had impos tence or bladder symptoms attributed to auto@ nomic neuropathy, and eight had no autonomiæ symptoms. Because it contained many patients with impotence the second group had a higher proportion of male patients but otherwise thê three groups were of comparable age and sex? None of the diabetics complained of oesophageas symptoms but one patient, who suffered froms diarrhoea, admitted to mild dysphagia on ques tioning. Five diabetics had mild heartburn and ath had autonomic symptoms ( 3 alimentary, 2 genitourinary).

For comparative purposes a group of 14 (1屯 male, 4 female) staff and patients without alimen? tary disease was studied. In all cases informed consent to the investigations was obtained.

METHODS

RADIOLOGY Patients swallowed $20 \mathrm{ml}$ of Micro角 paque and if the oesophagus was not cleared 'dry swallows at 30 -second intervals were made up t8 a time limit of 4 minutes. This examination was first done with the patient in the supine oblique position and was then repeated with the table 


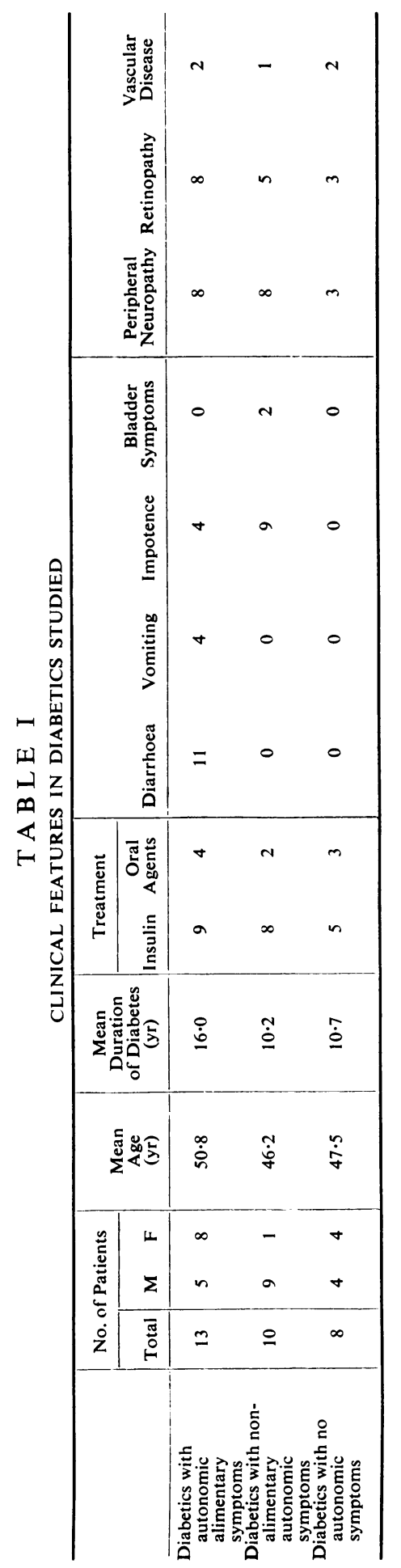


tilted $15^{\circ}$ head down. The procedures were screened intermittently and video tape recordings were made so that motility and rate of clearance of contrast from the oesophagus could be assessed. Films of the oesophagus using the undercouch tube were taken, and the maximum diameter of the oesophagus at any level between the aortic arch and the phrenic ampulla was measured.

Patients whose emptying time exceeded 1 minute in the head down position had the studies repeated 15 minutes after a subcutaneous injection of $2.5 \mathrm{mg}$ bethanechol, a cholinergic agent with muscarinic actions.

Oesophageal Manometry Oesophageal intraluminal pressure was measured in the fasting state through two open-ended water-filled polyethylene tubes $(1.5 \mathrm{~mm}$ internal diameter) with constant water perfusion at a rate of $0.5 \mathrm{ml} / \mathrm{min}$. The tips of the tubes were $5 \mathrm{~cm}$ apart. With the patient in the left lateral position, pressure in the lower oesophageal sphincter was recorded by withdrawing the tube through the cardia in steps of $1 \mathrm{~cm}$. Thereafter swallows of $10 \mathrm{ml}$ water were given and peristalsis was recorded from all levels of the oesophagus.

Studies were repeated 15 minutes after $2.5 \mathrm{mg}$ bethanecol, given subcutaneously to determine whether hypersensitivity to this agent, as occurs in achalasia (Kramer and Ingelfinger, 1951) and
Chagas' disease (Heitmann and Espinosa, 1969) was present.

\section{RESULTS}

RADIOLOGY The findings in 26 diabetics and 14 non-diabetics without oesophageal symptoms studied are shown in Tables II and III where it will be seen that in all the non-diabetics oeso $\vec{\omega}$ phageal emptying took less than 1 minute. In contrast 19 of the 26 diabetics showed delaye oesophageal emptying, and in 14 of these, contras medium remained in the gullet for more than $4 \mathrm{w}$ minutes. This delay was present in a greater prov portion of diabetics with symptoms attributable to autonomic neuropathy than in those without such symptoms. Bethanecol was given to those patients with delayed oesophageal emptying, and oeso $\varrho_{\bar{E}}$ phageal emptying times were reduced in all group of patients (Table III).

The mean diameter of the barium-filled oesophagus was slightly greater in the diabetic patients than in the non-diabetics but the difference was only significant in the group with bladder symp toms and impotence.

Tertiary contractions were seen much more्षे frequently in the diabetics than in the non-dia betics and their frequency was greater in diabetics with symptoms attributable to autonomic neuro pathy than in those without such symptoms

T A B L E I I

RADIOGRAPHIC FINDINGS

\begin{tabular}{|c|c|c|c|c|c|c|}
\hline & No. & $\underset{(y r)}{\operatorname{Mean} A g e}$ & $\begin{array}{c}\text { Oesophageal } \\
\text { Emptying } \\
\text { Time }>1 \mathrm{~min} .\end{array}$ & $\begin{array}{c}\text { Mean } \\
\text { Oesophageal } \\
\text { Diameter (mm) } \\
( \pm \text { ISD })\end{array}$ & $\begin{array}{c}\text { Tertiary } \\
\text { Contractions } \\
\text { Present }\end{array}$ & $\begin{array}{c}\text { Gastro- } \\
\text { oesophageal } \\
\text { Reflux Present }\end{array}$ \\
\hline \multirow{4}{*}{$\begin{array}{l}\text { Normal subjects } \\
\text { Diabetics with alimentary } \\
\text { autonomic symptoms } \\
\text { Diabetics with genitourinary } \\
\text { autonomic symptoms } \\
\text { Diabetics with no autonomic } \\
\text { symptoms }\end{array}$} & 14 & 49 & 0 & $28 \cdot 1 \pm 3 \cdot 8$ & 3 & 0 \\
\hline & 11 & 49 & 10 & $31 \cdot 3 \pm 10.9$ & 9 & 3 \\
\hline & 8 & 43 & 6 & $33.6 \pm 4.9$ & 5 & 3 \\
\hline & 7 & 52 & 3 & $33 \cdot 7 \pm 9 \cdot 0$ & 2 & 0 \\
\hline
\end{tabular}

T A B L E I I I

EFFECTS OF BETHANECOL ON OESOPHAGEAL EMPTYING TIME

\begin{tabular}{|c|c|c|c|c|c|}
\hline & \multirow[b]{2}{*}{ Bethanecol } & \multirow[b]{2}{*}{ No. of Patients } & \multicolumn{3}{|c|}{ Oesophageal emptying Time } \\
\hline & & & $<1$ min & $2-4 \min$ & $>4 \mathrm{~min}$ \\
\hline $\begin{array}{l}\text { Diabetics with alimentary } \\
\text { autonomic symptoms } \\
\text { Diabetics with genitourinary } \\
\text { autonomic symptoms } \\
\text { Diabetics with no autonomic } \\
\text { symptoms }\end{array}$ & $\begin{array}{l}\text { Pre } \\
\text { Post } \\
\text { Pre } \\
\text { Post } \\
\text { Pre } \\
\text { Post }\end{array}$ & $\begin{array}{r}10 \\
7 \\
8 \\
6 \\
7 \\
3\end{array}$ & $\begin{array}{l}0 \\
3 \\
2 \\
1 \\
4 \\
1\end{array}$ & $\begin{array}{l}\mathbf{4} \\
\mathbf{3} \\
1 \\
\mathbf{4} \\
\mathbf{0} \\
\mathbf{1}\end{array}$ & $\begin{array}{l}6 \\
1 \\
5 \\
1 \\
3 \\
1\end{array}$ \\
\hline
\end{tabular}


Gastro-oesophageal reflux of contrast medium was seen in six diabetics with autonomic symptoms but in none of those without such symptoms and in none of the non-diabetic patients.

Oesophageal Manometry Although tertiary contractions were commoner in diabetics with autonomic symptoms than in those without and in non-diabetics, oesophageal peristalsis remained coordinated in the majority. In those diabetics with alimentary and genitourinary autonomic symptoms $70 \%$ of swallows were followed by a coordinated peristaltic wave, which was only a slightly lower percentage than that for nondiabetics and diabetics without autonomic symptoms (Table IV). The maximum amplitude of the peristaltic wave was slightly lower in diabetics with autonomic symptoms than in the other groups but this difference was not significant.

The lower oesophageal sphincter pressure was significantly reduced in all groups of diabetics compared with the non-diabetic and normal group but did not differ between those diabetics with and those without autonomic symptoms. When detectable the sphincter showed normally coordinated relaxation on swallowing.

Effect of Bethanecol Bethanecol caused a slight increase in the maximum amplitude of oesophageal peristalsis in normal and non-diabetic subjects and also in all three groups of diabetic patients.

Lower oesophageal sphincteric pressure rose slightly after bethanecol in the normal group and more strikingly in each of the three groups of diabetics (Figure). The magnitude of the pressure increase was significantly greater in the diabetics than in normal subjects but did not differ between those with alimentary or genitourinary autonomic symptoms and those without (Table IV).

Although the increase in lower oesophageal sphincter pressure after bethanecol was greater in the diabetics than in normal subjects the final pressures obtained were comparable because of

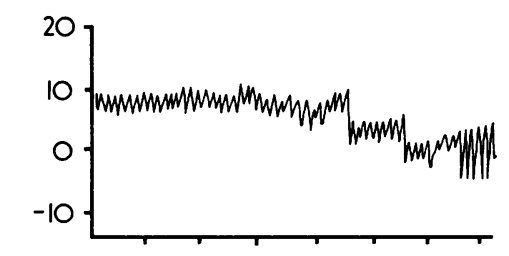

몰

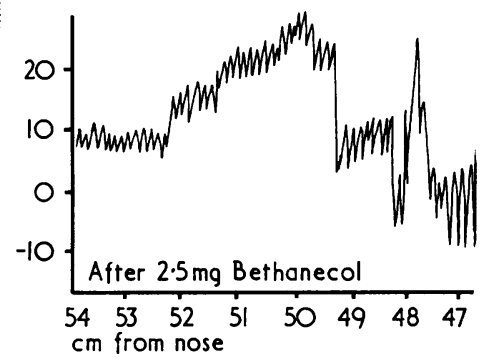

FIGURE Pressure recordings at the gastro-oesophageal junction in a diabetic with diarrhoea. The increase in pressure resulting from contraction of the lower oesophageal sphincter is inconspicuous (upper record) but becomes prominent 15 minutes after $2.5 \mathrm{mg}$ bethanecol given subcutaneously (lower record).

the lower initial pressures recorded from the diabetics. In only one diabetic, a man of 45 suffering from impotence, did the post-bethanecol lower oesophageal pressure reach a level $(40 \mathrm{mmHg})$ comparable with those found in Chagas' disease by Heitmann and Espinosa (1969) who used the same technique.

\section{DISCUSSION}

Our findings indicate that asymptomatic abnormality of oesophageal motility is common in diabetes. The radiological and manometric abnormalities detected agree well with those described by Mandelstam and his colleagues (Mandelstam

T A B L E I V

\begin{tabular}{|c|c|c|c|c|c|c|}
\hline & \multirow[b]{2}{*}{ No. of Patients } & \multirow{2}{*}{$\begin{array}{l}\text { Mean Amplitude } \\
\text { of Peristaltic } \\
\text { Wave (mmHg) } \\
( \pm \text { ISD) }\end{array}$} & \multirow{2}{*}{$\begin{array}{c}\text { Mean Percentage } \\
\text { of Swallows } \\
\text { followed by } \\
\text { Coordinated } \\
\text { Peristalsis }\end{array}$} & \multirow{2}{*}{$\begin{array}{c}\text { Tertiary } \\
\text { Contractions }\end{array}$} & \multicolumn{2}{|c|}{$\begin{array}{c}\text { Mean Lower Oesophageal } \\
\text { Sphincter Pressure (mmHg) } \\
( \pm \text { ISD) }\end{array}$} \\
\hline & & & & & Pre Bethanecol & Post Bethanecol \\
\hline Normals and non-diabetics & 11 & $25 \cdot 8 \pm 8 \cdot 3$ & 88 & 3 & $15 \pm 4 \cdot 7$ & $16 \cdot 2 \pm 3 \cdot 9$ \\
\hline $\begin{array}{l}\text { Diabetics with alimentary } \\
\text { autonomic symptoms }\end{array}$ & 12 & $22 \pm 6 \cdot 7$ & 70 & 8 & $8 \cdot 4 \pm 5 \cdot 2$ & $18 \cdot 8 \pm 2 \cdot 8$ \\
\hline $\begin{array}{l}\text { Diabetics with genitourinary } \\
\text { autonomic symptoms }\end{array}$ & 9 & $17 \cdot 4 \pm 10 \cdot 2$ & 70 & 6 & $7 \cdot 5 \pm 4 \cdot 5$ & $18 \cdot 8 \pm 6 \cdot 4$ \\
\hline $\begin{array}{l}\text { Diabetics with no } \\
\text { autonomic symptoms }\end{array}$ & 8 & $25 \pm 4.6$ & 89 & 4 & $8 \cdot 8 \pm 5 \cdot 7$ & $18 \cdot 0 \pm 5 \cdot 4$ \\
\hline
\end{tabular}


and Lieber, 1967; Mandelstam et al., 1969) and consisted of diminution of the amplitude of peristalsis, resulting in delayed oesophageal emptying in the recumbent position, frequent tertiary contractions, and loss of tone of the lower oesophageal sphincter which often led to gastrooesophageal reflux. Oesophageal peristalsis, albeit of reduced amplitude, remained properly coordinated in almost all our patients.

Degeneration of truncal vagal nerve fibres might well account for oesophageal motor changes in diabetics. In the dog, bilateral vagotomy at hilar or cervical level causes oesophageal dilatation with abolition of peristalsis and loss of tone in the lower oesophageal sphincter (Carveth et al., 1962; Higgs and Ellis, 1965). When truncal vagotomy is carried out for the treatment of duodenal ulcer the level of section is too low to affect peristalsis but the operation may lead to loss of tone of the lower oesophageal sphincter (Woodward, Alexander-Williams, and Atkinson, 1966). Furthermore, the gastric secretory response to insulininduced hypoglycaemia was subnormal in many of our patients, suggesting that vagal impairment was indeed present (Hosking et al., 1975).

Our findings suggest that in the diabetic the intramural myenteric plexus of the oesophagus is not severely damaged and the clinical, radiological, and manometric abnormalities are quite different from those seen in achalasia and Chagas' disease. Degeneration of the ganglion cells and post-ganglionic nerve fibres of the myenteric plexus leads to hypersensitivity of the oesophageal muscle to the cholinergic agents (Kramer and Ingelfinger, 1951). Heitmann and Espinosa (1969) demonstrated hypersensitivity to bethanecol in Chagas' disease, but, using the same dosage of this drug, we were unable to detect this in diabetic patients. Although bethanecol produced a greater increase in lower oesophageal sphincter pressure in diabetics than in normal subjects, since the initial levels were low in the diabetics those after bethanecol were not significantly higher in diabetics than in normals. In Chagas' disease Heitmann and Espinosa (1969) found a mean rise of $15.9 \mathrm{mmHg}$ in lower oesophageal sphincter pressure but the mean post-bethanecol sphincter pressure $(25.4 \mathrm{mmHg})$ was much higher than that of their normal subjects and exceeded that of our diabetics. The absolute level of lower oesophageal sphincter pressure after bethanecol seems a better criterion to use than does the pressure increase expressed as a percentage of the basal value. If the latter is low, even a small rise will represent a considerable percentage increase and furthermore there is evidence that the exaggerated respons seen after denervation may be related to the deve? opment of muscle hypertrophy which would cause higher absolute pressures to be generated. Hence we conclude that hypersensitivity to bethanecof is not characteristic of diabetes and it therefore seems likely that the myenteric plexus is function:ally intact.

Histopathological changes have been found i the autonomic nervous system in diabetic (Hensley and Soergel, 1968; Kristensson et al i.j 1971), and in the vagus patchy degeneration of myelin sheaths with fragmentation and granulaî change in the axon have been noted. The signifpo cance, extent, and frequency of these changes io diabetics is unknown and further studies, including ganglion cell counts for the eosophagea myenteric plexus, are needed.

The clinical significance of the oesophageat motor changes we have found remains uncertain None of our patients had severe dysphagia and $a f$ though in six gastro-oesophageal reflux was demonstrated radiologically, and five had associo ated symptoms, these were all mild. Gastrie secretory studies reported elsewhere (Hosking eकी al., 1975) indicated that many of our patients ha\& vagal impairment and the consequent reductio in acid secretion might protect against the de velopment of reflux oesophagitis.

We found no correlation between the severity of the oesophageal motor disturbance and the presence of alimentary autonomic symptoms i this group of diabetics. In the same group of patients parallel studies of gastric vagal function assessed by the gastric secretory response to insulin-induced hypoglycaemia, also indicated that vagal impairment was not greater in those witb alimentary than in those with genitourinary auto nomic symptoms (Hosking et al., 1975). Tw possible explanations for this apparent discrepanct. are that the vagal fibres supplying different parts of the gut may be affected in differing degree orv that other factors such as bacterial overgrowth in the intestine may precipitate symptoms.

\section{REFERENCES}

Carveth, S. W., Schlegel, J. F., Code, C. F., and Ellis, F. H., Jr. (1962). Esophageal motility aftes vagotomy, phrenicotomy, myotomy, and myo mectomy in dogs. Surgery, Gynecology an $\$$ Obstetrics, 114, 31 .

Dotevall, G. (1961). Gastric function in diabete mellitus: a clinical and experimental study with special reference to gastric secretion of acido Acta Medica Scandinavica, Supplement, 368 . 
Heitmann, P. and Espinosa, J. (1969). Oesophageal manometric studies in patients with chronic Chagas disease and megacolon. Gut, 10, 848.

Hensley, G. T. and Soergel, K. H. (1968). Neuropathologic findings in diabetic diarrhea. Archives of Pathology, 85, 587.

Higgs, B. and Ellis, F. H., Jr. (1965). The effect of bilateral supranodosal vagotomy on canine esophageal function. Surgery, 58, 828.

Hosking, D. J., Moody, F., Stewart, I. M., and Atkinson, M. (1975). Vagal impairment of gastric secretion in diabetic autonomic neuropathy. British Medical Journal, 2, 588.

Kassander, P. (1958). Asymptomatic gastric retention in diabetics (gastroparesis diabeticorum). Annals of Internal Medicine, 48, 797.

Kramer, P. and Ingelfinger, F. J. (1951). Esophageal sensitivity to Mecholyl in cardiospasm. Gastroenterology, 19, 242.

Kristensson, K., Nordborg, C., Olsson, Y., and Sourander, P. (1971). Changes in the vagus nerve in diabetes mellitus. Acta Pathologica et Microbiologica Scandinavica, 79A, 684.

Malins, J. M. and Mayne, N. (1969). Diabetic diarrhea. Diabetes, 18, 858.
Mandelstam, P. and Lieber, A. (1967). Esophageal dysfunction in diabetic neuropathy-gastroenteropathy. Journal of the American Medical Association, 201, 582.

_ Siegel, C. I., Lieber, A., and Siegel, M. (1969). The swallowing disorder in patients with diabetic neuropathy-gastroenteropathy. Gastroenterology, 56, 1 .

Rundles, R. W. (1945). Diabetic neuropathy: general review with a report of 125 cases. Medicine (Baltimore), 24, 111.

Silber, W. (1969). Diabetes and oesophageal dysfunction. British Medical Journal, 3, 688.

Whalen, G. E., Soergel, K. H., and Geenen, J. E. (1969). Diabetic diarrhea: a clinical and pathophysiological study. Gastroenterology, 56, 1021.

Woodward, D. A. K., Alexander-Williams, J., and Atkinson, M. (1966). Effect of subdiaphragmatic vagotomy on the function of the gastro-oesophageal sphincter. Gut, 7, 713.

Requests for reprints to: Dr. M. Atkinson, The General Hospital Nottingham. 